\title{
SEASONAL DIET SHIFTS OF SEVEN FISH SPECIES IN AN ATLANTIC RAINFOREST STREAM IN SOUTHEASTERN BRAZIL
}

\author{
DEUS, C. P. ${ }^{1}$ and PETRERE-JUNIOR, M. ${ }^{2}$ \\ ${ }^{1}$ Instituto Nacional de Pesquisas da Amazônia, Coordenação de Pesquisas em Biologia Aquática, \\ C.P. 478, CEP 69011-970, Manaus, AM, Brazil \\ ${ }^{2}$ IB/Departamento de Ecologia UNESP, Campus de Rio Claro, C.P. 199, CEP 13506-900, Rio Claro, SP, Brazil \\ Correspondence to: Cláudia Pereira de Deus, Instituto Nacional de Pesquisas da Amazônia, Coordenação de \\ Pesquisas em Biologia Aquática, C.P. 478, CEP 69011-970, Manaus, AM, Brazil, e-mail: claudias@inpa.gov.br \\ Received April 22, 2002 - Accepted August 6, 2002 - Distributed November 30, 2003
}

(With 3 figures)

\begin{abstract}
We analyzed the stomach contents of 116 individuals belonging to seven fishes species in order to investigate seasonal changes in feeding strategy and how trophic interactions between species affect community structure in an Atlantic rainforest stream in Southeastern Brazil. Oligosarcus hepsetus and Pimelodus sp. consumed fewer items during the winter. Phalloceros caudimaculatus switched feeding habits from detritus during summer to algae during winter. These examples are related to variations in food availability and species feeding selectivity. The highest diet overlap values, for most species, as measured using Schoener's index, were observed in summer, along with a species tendency to be more generalist. Feeding pattern variation may influence the fish community structure.
\end{abstract}

Key words: Atlantic rainforest, diet overlap, feeding variability, specialist, generalist.

\section{RESUMO}

Mudanças sazonais na dieta de sete espécies de peixes de um riacho de Mata Atlântica no Sudeste do Brasil

Nós analisamos o conteúdo estomacal de 116 indivíduos pertencentes a sete espécies de peixes, no intuito de investigar as mudanças sazonais na estratégia alimentar e como interações tróficas entre as espécies afetam a estrutura de comunidade em um riacho de Mata Atlântica no Sudeste do Brasil. Oligosarcus hepsetus e Pimelodus sp. consumiram menos itens durante o inverno. Phalloceros caudimaculatus mudou o hábito alimentar de detrito durante o verão para algas durante o período de inverno. Esses exemplos são relacionados às variações na disponibilidade de alimento e na seletividade alimentar das espécies. Os mais altos valores de sobreposição alimentar, para a maioria das espécies, medidos pelo índice de Schoener, foram observados no verão, quando as espécies tenderam a ser mais generalistas. A variação no padrão alimentar pode influenciar a estrutura das comunidades de peixes.

Palavras-chave: Mata Atlântica, sobreposição de dieta, variabilidade alimentar, especialista, generalista.

\section{INTRODUCTION}

Food web analysis is one of the most important areas in community structure research. Understanding how organisms utilize resources allows identification of factors that affect their distribution and abundance. This justifies the study of tropho-dynamic aspects and biological interactions between species, such as predation and competition. A still important concern raised by Paine (1966) is the necessity of understanding the food web complexity within ecological systems; the relationship between physical, biological, genetical and environmental factors; and how these relationships affect species diversity (Martinez \& Lawton, 1995; McCann et al., 1998; Polis, 1998). 
This discussion is based on Gause's principle of competitive exclusion. Several mathematical models predict that in communities that have reached a competitive equilibrium, species may coexist due to resource partitioning. However, there should be a species richness limit imposed by physical factors and extent of available limiting resources (MacArthur, 1965). Some observations about the role of competitive interactions on local community structure have changed this point of view. Thus, when competitive interactions are weak, there may be no limit on the number of species coexisting in a community (Caswell, 1976), as suggested by the classical formulation of Lotka-Volterra. Even in strongly competitive communities, there are examples of species richness being locally high, depending on spatio-temporal heterogeneity (Cornell \& Lawton, 1992).

Knowledge of how species share available resources, the niche breadth, and the degree of overlap among them within a community make it possible to understand the structure of the community and, indirectly, its diversity. In this work, we attempted to answer the following question: Do species change their feeding strategies between summer and winter?

\section{MATERIAL AND METHODS}

\section{Study site}

This study was carried out on the Itinguçu River $\left(24^{\circ} 23^{\prime} \mathrm{S}, 4^{\circ} 07^{\prime} \mathrm{W}\right)$ in the Juréia-Itatins Ecological Station (Fig. 1) in Peruíbe, São Paulo State, Brazil. This river starts on a hilltop and flows into another plain river (Una do Prelado). In the region of Juréia, the landscape is mountainous, presenting in some parts altitudes of over 300 meters. Small stones cover the stream bed. Itinguçu stream has clear water, mean temperatures of $23^{\circ} \mathrm{C}$ in summer and $17^{\circ} \mathrm{C}$ in winter, and a current mean velocity of around $26 \mathrm{~cm} / \mathrm{s}$. Rains are more intensive in tropical rainforest streams, during the summer period (from December to May), and water volume in the channel is higher compared with that of the winter period (from June to November) when rains are scarcer. In summer, water overflows the edges, expanding stream width and reaching a mean value of 28.8 meters. In winter, mean width is about two meters less. Mean depth varies from $1.00 \pm 0.38$ $\mathrm{cm}$ in summer to $0.71 \pm 0.39 \mathrm{~cm}$ in winter. We selected four sampling stations, based on their physiographic characteristics. All analyzed species occurred in the four sampling sites throughout the year. We considered that there was no spatial segregation among them, which is why the samples were pooled together.

\section{Feeding analysis}

Fishes were collected during daylight, from January to March (summer) and from June to August (winter) in 1997 using gillnets and handnets. They were preserved in $10 \%$ formalin solution, then transferred to $70 \%$ alcohol solution. We analyzed the stomach contents of 116 individuals (only adults, to avoid ontogenetic variations) belonging to seven species: traíra, Hoplias malabaricus (15.8-19.7 cm SL, $\mathrm{n}=$ 8-6 for summer and winter, respectively); Erythrinidae; dogfish, Oligosarcus hepsetus (14.1-18.7 cm SL, n = 9-6), Characidae; lambari, Deuterodon iguape (8.1$9.4 \mathrm{~cm} \mathrm{SL}, \mathrm{n}=8-9)$, Tetragonopterinae, Characidae; saguairú, Cyphocharax santacatarinae $(9.9-14.7 \mathrm{~cm}$ SL, n =10-10), Curimatidae; guarú, Phalloceros caudimaculatus (3.2-4.5 cm SL, $\mathrm{n}=10-10)$, Poeciliidae; mandí, Pimelodus sp. (14.8-18-2 cm SL, $\mathrm{n}=9-6$ ), Pimelodidae; and catfish, Rhamdia quelen (16.7-18.3 cm SL, n = 8-9), Pimelodidae. We selected species that reached the highest occurrence frequencies year round to analyze diet variations between summer and winter. Another 31 species were part of this fish community. Because some of them did not appear in both seasons and others were rare species with low population density during the whole year, they were excluded from this analysis.

We used the Costello (1990) method with Amundsen et al. (1996) modifications. This analysis is based on a graphical representation (Fig. 2), making it possible to explore ingested food types, data in relation to feeding strategies, as well as intra- and interindividual shifts in niche utilization. On this graphic, the first diagonal represents abundance increase along with prey importance. The vertical axis represents predator strategy going from generalist to specialist. The second diagonal axis represents resource use changing from BPC (between phenotype component, among individuals of population) to WPC (withinphenotype component - tending towards the same resource use). Graph interpretation of fish feeding strategies based on our data follows the Amundsen et al. (1996) procedure illustrated in Fig. 2, where coordinates $\mathrm{x}$ and $\mathrm{y}$ represent occurrence and abundance of items, respectively. Food items were classified among three groups (as shown in Table 1). 


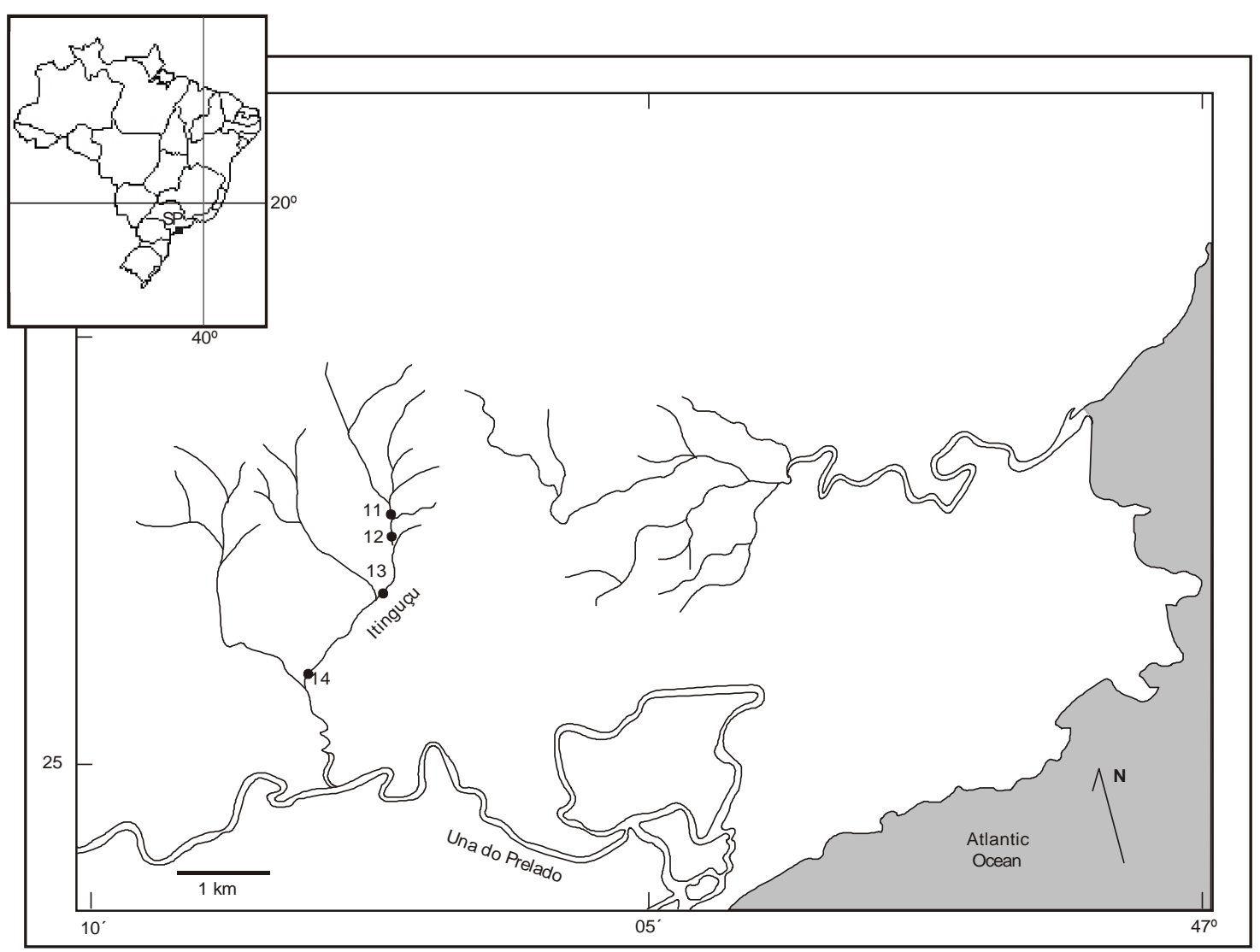

Fig. 1 - Map of the study area located in São Paulo State (SP) and the sampling sites in the Itinguçu Stream.

Initially, the individuals were classified according to summer and winter collections. Consumed food items were recorded, using a numerical method for most species. Volumetric measurement was used for species whose diets were mainly composed of detritus and algae (Hyslop, 1980).

To compute feeding selectivity for each season, we used the Lawlor (1980) electivity index, i.e., the ratio of each food item between stomachs of one particular species and stomachs of all species:

$$
P X_{i}=\frac{X_{i}}{\sum i}
$$

where $X_{i}=$ quantity of item $\mathrm{i}$ (number or volume) in stomach of specie $i$ and $\sum i=$ sum of item $i$ (number or volume) in all stomachs of all species present in a season. According to Winemiller (1989), in this procedure the fish is regarded as being an estimator of the available resources in the environment. To compute diet overlap between species, we used the Schoener (1970) index $\alpha$ that varies between 0 (lack of diet overlap) and 1 (total overlap). In the original formulation, for each fish species we substituted the proportion of each food item by its electivity value, so it could be interpreted as indicative of food item availability in the environment (Winemiller, 1989; Winemiller \& Kelso-Winemiller, 1996):

$$
\alpha=1-0.5\left(\sum_{i=1}^{n}\left|P X_{i}-P y_{i}\right|\right)
$$

where $\mathrm{Px}_{\mathrm{i}}, \mathrm{Py}_{\mathrm{i}}=$ resource electivity $\mathrm{i}$ for species $\mathrm{x}$ and $\mathrm{y} ; \mathrm{n}=$ total number of resources. 


\section{RESULTS}

\section{Feeding strategy}

Of the seven fish species analyzed, only $O$. hepsetus, D. iguape, Pimelodus sp., and $P$. caudimaculatus switched their diets between summer and winter. In summer, the O. hepsetus (Fig. 3) diet comprised nine food item. Some individuals specialized in fish, Miriapoda, and Hymenoptera. In winter, this species limited the range of consumed items to fish, Coleoptera, and spiders. No prey was predominant for $O$. hepsetus. The variability in resource breadth between individuals was high (high variation between phenotypes). The diet of $D$. iguape varied from summer to winter. In summer (Fig. 3), the consumption of detritus and algae was uniform among individuals (99\% of occurrence frequency); they also ate small invertebrates ( $85.7 \%$ of occurrence frequency). In winter, this species ate five food items, predominantly filamentous algae. We regarded this species as specializing in this food item during the winter. Ingestion of invertebrates was also frequent. Fish scales, shrimp, and detritus might be only accidentally ingested as they occurred in less than $20 \%$ of individuals analyzed. The low variation in resource use during the winter suggests high specialization in the diet of individuals of $D$. iguape during this season. The diet of Pimelodus sp. varied, with 11 food items during summer and 7 in winter (see Fig. 3). In summer, some individuals were specialists in Tanaidacea and Diptera. However, the most important item during this season for most of the individuals was Gastropoda (bivalves). In summer, some items such as Hymenoptera, Odonata, Orthoptera, crabs, Acarina, spiders (Ctenidae), Ostracoda, and shrimps were consumed by less than $20 \%$ of analyzed individuals, thus being insignificant. This result suggests that, during summer, Pimelodus sp. was more opportunistic. In winter, some items such as acarina, ants, and gastropods, were still being consumed. A higher proportion of the analyzed individuals, however, fed mainly on gastropods, showing a tendency for specialization during this season.

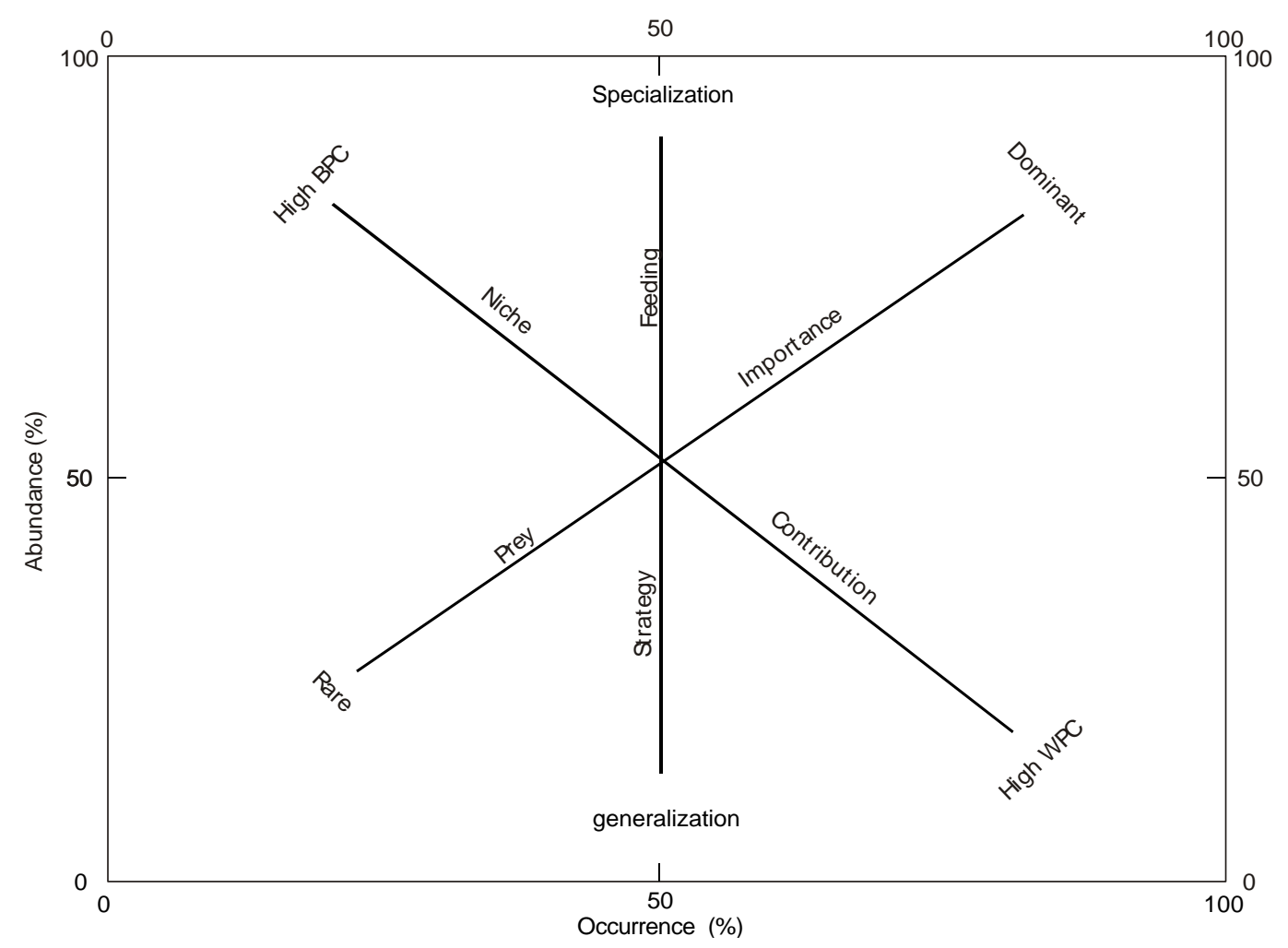

Fig. 2 - Schematic representation of species feeding strategies proposed by Costello (1990) and modified by Amundsen et al. (1996). See text for explanation. 
TABLE 1

Food items ingested by studied species. Identification codes are in parenthesis.

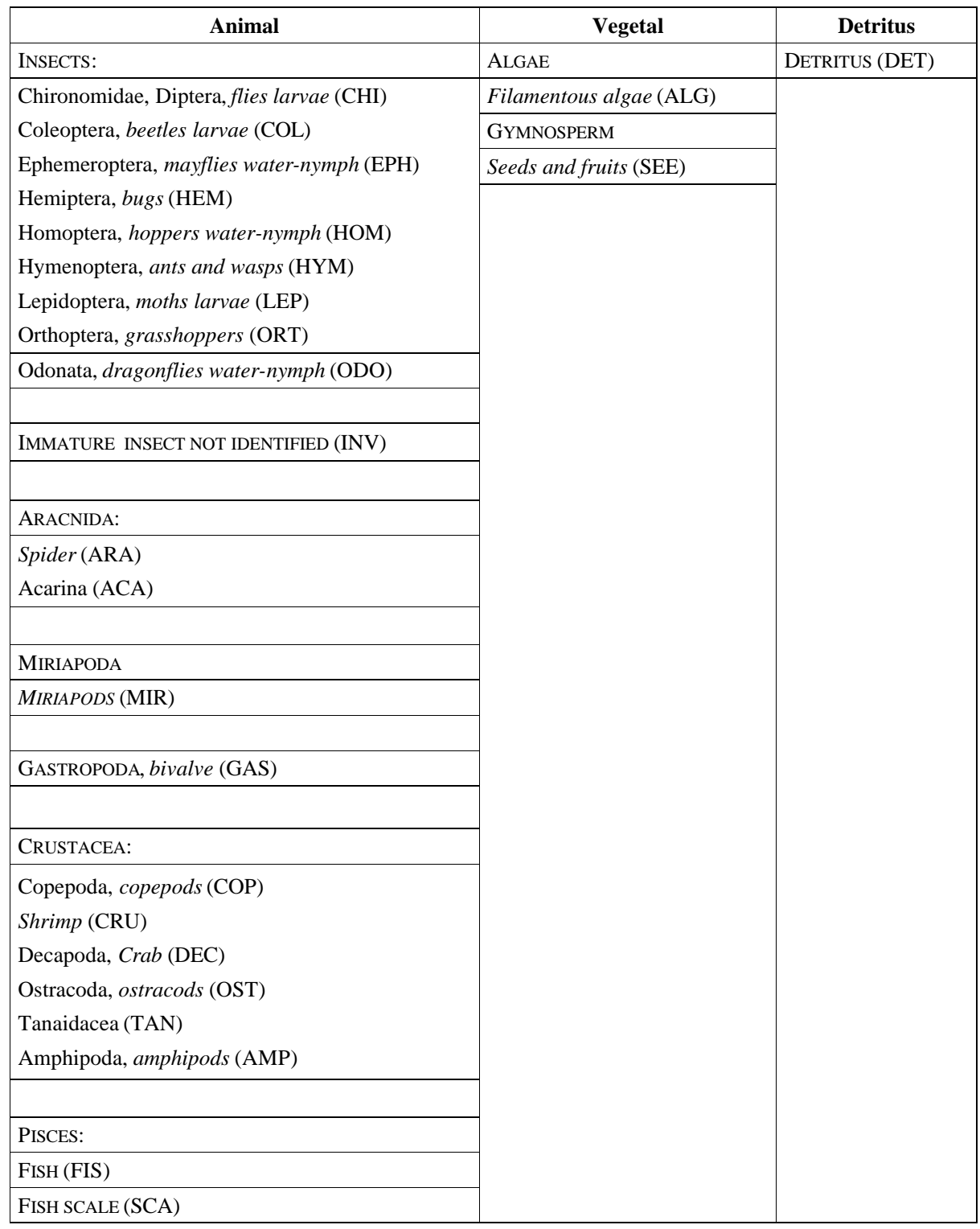

Fish was the main item in the diet of $H$. malabaricus, during summer and winter, suggesting that this species is obligate piscivore. Ingestion of shrimp was observed in the summer (6.82\% of analyzed stomachs) and, to a higher degree, during the winter (100\% of analyzed stomachs). Hoplias malabaricus preyed mainly on lambari (D. iguape), mandí (Pimelodella sp.) and guaru (P. caudimaculatus).

Cyphocharax santacatarinae had a diet similar in summer and winter (Fig. 3). Detritus was the exclusive food item for all analyzed individuals, showing that this species is obligate detritivore. The diet of $P$. caudimaculatus changed little throughout the year. There was a predominance of detritus with complementary algae ingestion during summer and winter, and few invertebrates during the winter. Rhamdia quelen had a diverse diet, on the average composed of ten food items. Resource use variation was higher during summer (Fig. 3), suggesting a more generalist strategy during this season. In winter, the majority of the prey was consumed in smaller proportions by a small number of individuals. However, 
more seeds (almost 100\%) were ingested in comparison with summer. This indirectly suggests that seed availability was higher during winter. The number of individuals that fed on crabs was higher during winter, and this item is an important food source for this species. The feeding strategy of $R$. quelen during the study period varied in the degree of specialization and generalization for different prey types.

\section{Diet overlap}

For the species that fed on insects and detritus we observed that, during winter, D. iguape relied preferentially on algae, which led to an increase in diet overlap with $P$. caudimaculatus $(\alpha=0.73$ ) (as shown in Table 2). Conversely, the switch from detritus (summer) to algae (winter) as the main food for D. iguape decreased the overlap with $C$. santacatarinae during the winter (Table 2). In some sampling sites, the three species were sympatric, which suggests food partitioning. Between $O$. hepsetus and $H$. malabaricus, the overlap was higher during winter $(\alpha=0.93)$. Oligosarcus hepsetus substantially restricted the number of food items ingested, and increased the number of beetle larvae (Coleoptera) consumed. Fishes were still ingested by this species, although the decrease in item variety might have induced an increase in the overlap between the two species. It was also observed that during winter more individuals of $H$. malabaricus consumed shrimp. This suggests a type of diet shift that reduced competition between these two species. The pattern opposite to decreasing overlap was observed in relation to that between $O$. hepsetus, Pimelodus sp., and $R$. quelen. The frequency and quantity of the several food items shared among $O$. hepsetus and the other two species were lower during winter. All three species modified their diets in winter, reducing the variety of items consumed and tending to specialization. $R$. quelen ingested mainly seeds and Pimelodus sp. preferred gastropods during this period.

TABLE 2

Diet overlap (Shoener's Index) among species in winter. Species code: $\mathbf{P}$. cau = Phalloceros caudimaculatus $;$ D. igu = Deuterodon iguape $;$ C. san = Cyphocharax santacatarinae $;$ O. hep = Oligosargus hepsetus $;$ H. mal = Hoplias malabaricus; R. que = Rhamdia quelen $;$ Pim sp. = Pimelodus sp.

\begin{tabular}{|l|c|c|c|c|c|c|}
\hline \multicolumn{1}{|c|}{ Species } & P. cau & D. igu & C. san & O. hep & H. mal & R. que \\
\hline P. cau & - & & & & & \\
\hline D. igu & 0.73 & - & & & & \\
\hline C. san & 0.50 & 0.66 & - & & & \\
\hline O. hep & 0.00 & 0.00 & 0.00 & - & & \\
\hline H. mal & 0.00 & 0.00 & 0.00 & 0.93 & - & \\
\hline R. que & 0.00 & 0.00 & 0.00 & 0.05 & 0.25 & - \\
\hline Pim sp. & 0.00 & 0.20 & 0.00 & 0.30 & 0.00 & 0.53 \\
\hline
\end{tabular}

TABLE 3

Diet overlap (Shoener's Index) among species in summer. Species code: P. cau = Phalloceros caudimaculatus $;$ D. igu = Deuterodon iguape $;$ C. san = Cyphocharax santacatarinae $;$ O. hep = Oligosargus hepsetus; $\mathrm{H} . \mathrm{mal}=$ Hoplias malabaricus; R. que = Rhamdia quelen $;$ Pim sp. = Pimelodus $\mathbf{s p .}$

\begin{tabular}{|c|c|c|c|c|c|c|}
\hline Species & P. cau & D. igu & C. san & O. hep & H. mal & R. que \\
\hline P. cau & - & & & & & \\
\hline D. igu & 0.40 & - & & & & \\
\hline C. san & 0.76 & 0.76 & - & & & \\
\hline O. hep & 0.00 & 0.10 & 0.00 & - & & \\
\hline H. mal & 0.00 & 0.00 & 0.00 & 0.24 & - & \\
\hline R. que & 0.10 & 0.10 & 0.00 & 0.94 & 0.32 & - \\
\hline Pim sp. & 0.10 & 0.10 & 0.00 & 0.87 & 0.12 & 0.87 \\
\hline
\end{tabular}



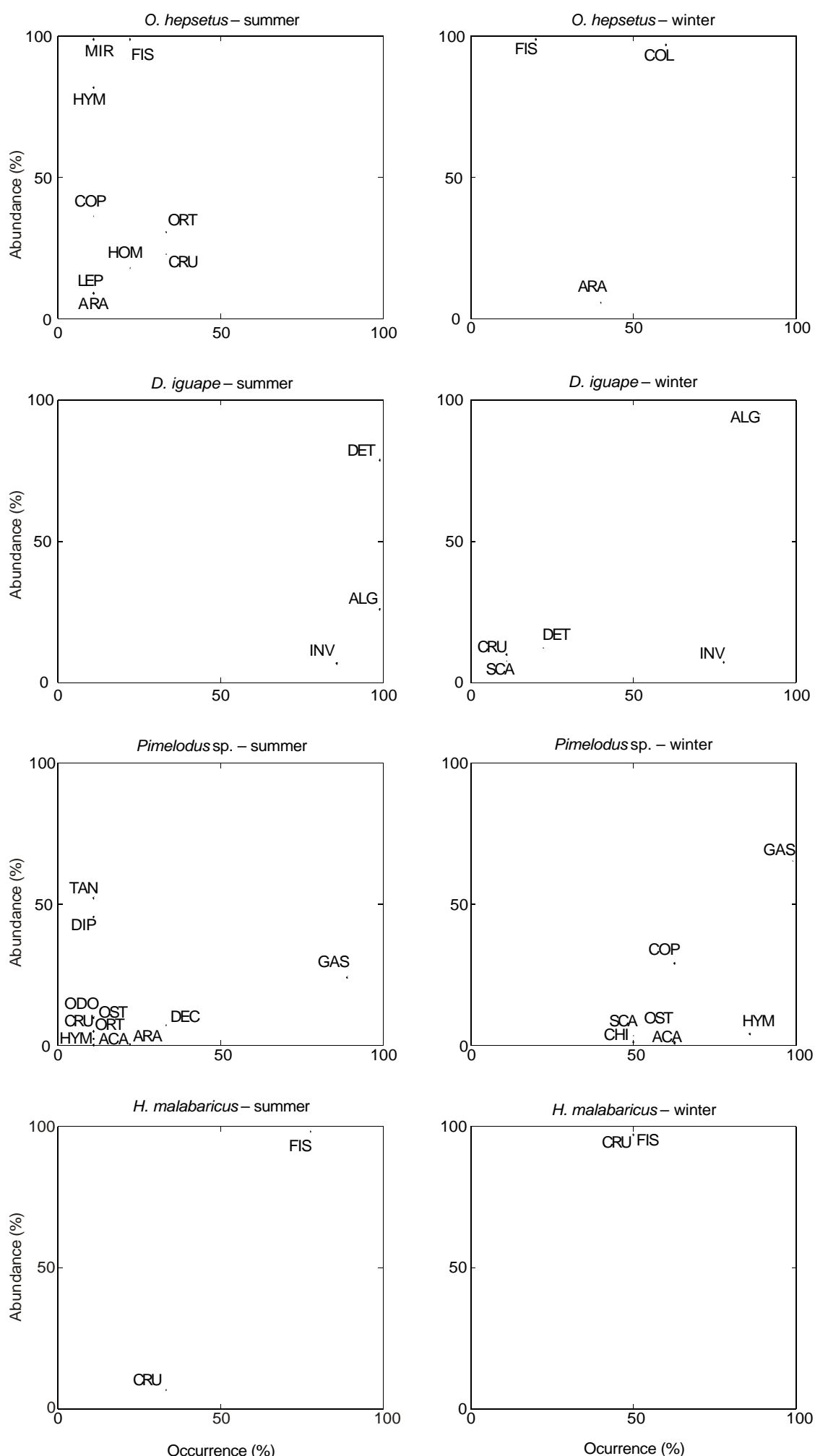

Fig. 3 - Feeding strategy diagrams. Niche contribution and prey importance of some fish species in summer and winter. Specific abundance against frequency of occurrence of food items. Identification codes as in Table 1 . 

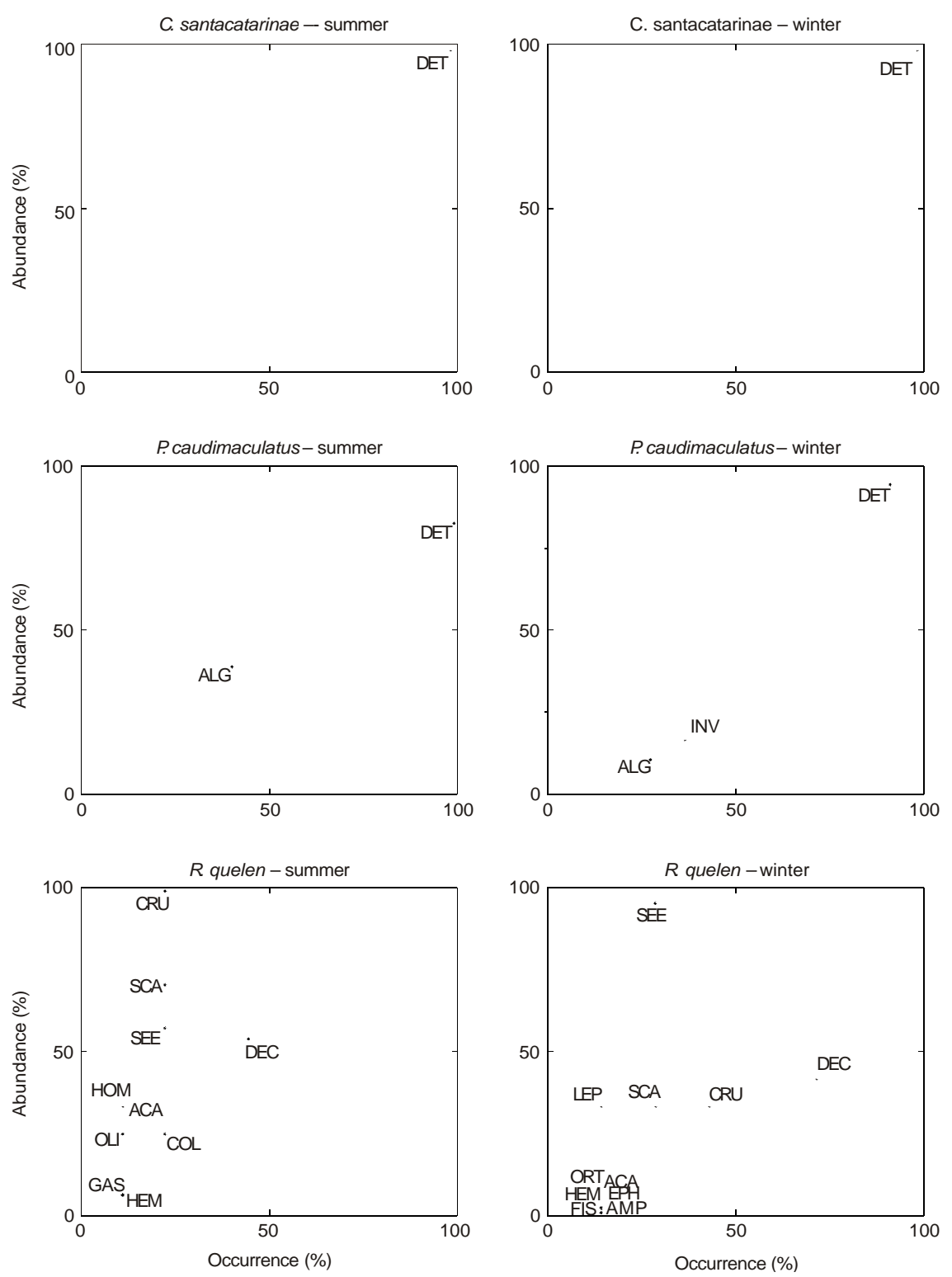

Fig. 3 - Feeding strategy diagrams. Niche contribution and prey importance of some fish species in summer and winter. Specific abundance against frequency of occurrence of food items. Identification codes as in Table 1 (continued).

\section{DISCUSSION}

Fishes that inhabit streams feed preferentially on aquatic invertebrates (Silva, 1993). Walker (1990) estimated that, for Amazonian streams, an invertebrate density of about 382 ind. $\mathrm{m}^{-2}$ is available for food use by the fishes. Uieda et al. (1997) noted the importance of aquatic invertebrates as food for fishes inhabiting tropical streams. In our study the high contribution of insect larvae and microcrustaceans to the diet of species confirms this tendency. Changes in resource availability can lead to changes in a species' diet. However, these variations usually occur in frequency or quantity of items consumed.

Diet changes from summer to winter might be due to seasonal modifications in the invertebrate community (Flecker \& Feifarek, 1994), i. e., resource availability is affected by its temporal and spatial 
distribution (Martinez \& Lawton, 1995). Some species display a more plastic feeding behavior and this fact allows for low-cost dietary changes. Dietary are a changes feeding behavior feature of several species (Gerking, 1994). The cost-benefit relationship (optimum foraging theory) during foraging can reach a threshold where a particular type of food chosen might have previously been refused. These changes, which are related to resource availability, are adaptive as they allow the individuals to survive in conditions that would otherwise be disadvantageous (Gerking, 1994).

Lack of food availability assessment restricted the precision level reached with our results. This has been one of the major problems in fish-feeding study, especially in the tropics where many abiotic factors, in addition to genetic characteristics of the species themselves, act together. However, it was possible to note that species were more generalist in summer and more specialist in winter. According to Wallace Jr. (1981), food similarity is biologically significant when $\alpha$ (Schoener's index) is higher than 0.6. The food overlap index between $P$. caudimaculatus and D. iguape changed due to this last species consuming more algae during the winter. On the other hand, the overlap between $P$. caudimaculatus and $C$. santacatarinae decreased during the winter. The probable reason is because $P$. caudimaculatus increased its feeding spectra at that time. The overlap between $O$. hepsetus, $H$. malabaricus, $R$. quelen, and Pimelodus sp. pair by pair revealed a dynamic diet pattern between summer and winter. The electivity value led us to infer that resource availability clearly changed during our study period. Pyke et al. (1977) and Liem (1984) believe that a generalist feeding strategy is favored when the food density is low or constantly fluctuating. However, ecological notions relevant to the trophic relations are somewhat controversial. Examples described by Gerking (1994) show that food shortage might lead to specialization. Werner \& Hall (1976) observed a similar pattern in two species of Centrarchidae. With the progressive decline in food resources, there was a more pronounced segregation in diet and habitat use between the two species.

Difference in diet overlap index of species between summer and winter indicated variation in food availability. Based on our field observations, we believe that food diversity at least was higher in summer. The apparent greater food diversity can have led to higher food overlap between species in summer. Matthews (1998), based on a hypothetical overlap of the resource use as a function of habitat availability, suggested that at "moderate" levels of resource availability the species could diverge in their food niche by becoming specialists, thus decreasing the overlap. However, in extreme situations of "high" or "low" abundance of resources, it is possible to find high overlap degrees. When resource availability is high the species may make use of it opportunistically, becoming generalist. In this case, despite the high overlap degree, the species would not necessarily compete, as the resource is highly abundant. At the other extreme, when resource availability is low, the species may converge on an identical resource. In this case the overlap would also be high and would probably lead to competition. The species would tend to be generalist not because of the high number of items available but due to food shortage.

If we rely on Matthew's arguments and on our evidence that food availability is higher in summer, we could say that there was no competition and the species were more generalist in this period, so much so that even diet overlap has been high in some cases. But feeding mechanisms that lead to specialization or generalization in the diet are not yet properly defined. This question is broad and has so far barely been addressed. Furthermore, morphological and physiological specialization can also influence fish feeding behavior and must be considered.

Based on our observations, change in feeding strategy was caused by extrinsic factors (variation in availability of some foods during the year) and is an adaptive response. The species genotype as a response to availability variation is what determines a strategic feeding adjustment. Specialist species such as $H$. malabaricus and $C$. santacatarinae were successful in foraging due to year-round food availability.

When the preferred food of a specialist species undergoes availability variation during the year, there are various consequences. Competition arises when different individuals or species are limited by space or a given resource and one necessarily deprives the other (Walker, 1993). In winter, the specialization tendency observed by the majority of the species studied must have been a way to minimize the competition process and it may indicate that food abundance has generally diminished. Even when competition is significant, its influence can be felt 
by only a small proportion of the species interacting within a community.

Questions about the effects of competition on freshwater (river) diversity may be studied through experiments or by testing appropriate neutral models, which await development. As stated previously, lack of real assessment of food quantity available in the environment is the major constraint on the reliability of data interpretation in fish feeding study. However, the use of the electivity index produces in more accurate results (Winemiller \& Kelso-Winemiller, 1996). What can be done in future work is to calibrate the electivity index, and then compare the estimated food availability with actual assessment of food quantity in the environment. This would result in higher precision of estimates.

Acknowledgments - We thank Dr. Sidinéia Amadio and Dr. Lúcia Rapp Py-Daniel for critical comments on the manuscript. We also thank Mr. Jorge Antunes for helping with the English corrections. This study is part of the Ph.D. thesis of the first author and was financed by Fapesp (process n. 96/1794). Capes provided a scholarship for the first author.

\section{REFERENCES}

AMUNDSEN, P. A., GABLER, H. M. \& STALDVIK, F. J., 1996, A new approach to graphical analysis of feeding strategy from stomach contents data - modification of the Costello (1990) method. J. Fish Biol., 48: 607-614.

CASWELL, H., 1976, Community structure: a neutral model analysis. Ecol. Monog., 46: 327-354.

CORNELL, H. V. \& LAWTON, J. H., 1992, Species interactions, local and regional processes, and limits to the richness of ecological communities: a theoretical perspective. J. Anim. Ecol., 61: 1-2.

COSTELLO, M. J., 1990, Predator feeding strategy and prey importance: a new graphical analysis. J. Fish Biol., 36: 261263.

FLECKER, A. S. \& FEIFAREK, B., 1994, Disturbance and the temporal variability of invertebrate assemblages in two Andean streams. Fresh. Biol., 31: 131-142.

GERKING, S. D., 1994, Feeding ecology of fish. Academic Press.

HYSLOP, E. J., 1980, Stomach contents analysis - a review of methods and their application. J. Fish Biol., 17: 411-429.
LAWLOR, L. R., 1980, Similarity and competition coefficients. Ecology, 61: 245-251.

LIEM, K. F., 1984, functional versatility, speciation, and niche overlap: are fishes different? In: G. Dewey, Meyers \& J. Rudi Strickler (eds.), Trophic interactions within aquatic ecosystems. AAAS Selected Symposium, Westview Press, Inc., Colorado.

MAcARTHUR, J. W., 1965, Patterns of species diversity. Biol. Ver., 40: 510-533.

MARTINEZ, N. D. \& LAWTON, J. H., 1995, Scale and foodweb structure - from local to global. Oikos, 73: 148-154.

MATTHEWS, W. J., 1998, Patterns in freshwater fish ecology. Chapman \& Hall.

McCANN, K., HASTINGS, A. \& HUXEL, G. R., 1998, Weak trophic interactions and the balance of nature. Nature, 395: 794-797.

PAINE, R. T., 1966, Food web complexity and species diversity. Am. Nat., 100(910): 65-75.

POLIS, G. A., 1998, Stability is woven by complex webs. Nature, 395: 744-745.

PYKE, G. H., PULLIAM, H. R. \& CHARNOV, E. L., 1977, Optimal foraging: a selective review of theory and tests. The Quat. Ver. of Biol., 52(2): 137-154.

SCHOENER, T. W., 1970, Nonsynchronous spatial overlap of lizards in patchy habitats. Ecology, 51: 408-418.

SILVA, C. P. D., 1993, Alimentação e distribuição espacial de algumas espécies de peixes do igarapé do Candirú, Amazonas, Brasil. Acta Am., 23: 271-285.

UIEDA, V. S., BUZZATO, P. \& KIKUSHI, R. M., 1997, Partilha de recursos alimentares em peixes em um riacho de serra do Sudeste do Brasil. Na. Acad. Bras. Ci., 69: 243-252.

WALKER, I., 1990, Ecologia e biologia dos igapós e igarapés. Ciência Hoje, 11: 44-53.

WALKER, I., 1993, Competition and information. Acta Biotherica, 41: 249-266.

WALLACE Jr., R. K., 1981, An assessment of diet-overlap indexes. Trans. Am. Fish. Soc., 110: 72-76.

WERNER, E. E. \& HALL, D. J., 1976, Niche shifts in sunfishes: experimental evidence and significance, Science, 191: 404406.

WINEMILLER, K. O., 1989, Ontogenetic diet shifts and resource partitioning among piscivorous fishes in Venezuelan llanos. Environ. Biol. Fish., 26: 177-199.

WINEMILLER, K. O. \& KELSO-WINEMILLER, L. C., 1996, Comparative ecology of catfishes of the upper Zambesi river floodplain. J. Fish Biol., 49: 1043-1061. 